\title{
NORMAS EDITORIAIS DA REVISTA DA FACULDADE DE DIREITO DA UNIVERSIDADE DE SÃO PAULO
}

\author{
EDITORIAL NORMS OF THE UNIVERSITY OF SÃO PAULO LAW SCHOOL REVIEW
}

a. Todos os artigos deverão vir acompanhados de disquete e em impresso;

b. O título dos trabalhos redatoriais deverá vir em língua portuguesa e em língua inglesa, e terá de estar em letras maiúsculas e em negrito e, se houver, subtítulo, em caixa baixa e em negrito;

c. A qualificação do autor deve constar no rodapé da primeira página impressa do trabalho, indicado por um asterisco, que virá tanto após o nome completo do autor quanto no rodapé. Após a titulação, solicita-se no máximo 03 (três) qualificações do autor e, em caso de interesse do autor, a indicação de endereço eletrônico;

d. Se o trabalho tiver subdivisões, os ítens e subítens deverão vir em números arábicos. Após os ítens e subítens não deverá constar pontuação;

e. Todos os artigos deverão ter Resumo em português e em inglês (Abstract). O Resumo não pode exceder 250 palavras;

f. Todos os artigos deverão ter palavras-chave, no máximo 10 (dez), e em inglês (keywords);

g. Os trabalhos deverão ter o corpo de letra n. 10, em folhas A4. As notas de rodapé deverão ter o corpo de letra n. 08, em Caixa Baixa. E em Caixa Alta, o sobrenome dos autores; e o da obra, em Italic, em Caixa Alta e Baixa;

h. Todos os trabalhos têm de ter obrigatoriamente a Bibliografia que, na Revista, constará com a designação Referências;

i. A imagem ou foto tem de possuir a qualidade de 300 DPI e o formato em JPG ou, preferencialmente, ser entregue a foto original;

j. O autor deverá fazer constar, no final do artigo, a data e o local em que foi escrito o trabalho de sua autoria.

k. O Sumário (título e resumo) da Revista será divulgado no site da FDUSP, para o qual os autores concedem prévia autorização de publicação. 


\section{SERVIÇO TÉCNICO DE IMPRENSA}

Eduardo Carlos Bianca Bittar, Professor Associado (Presidente)

Tales Picchi Alves, Assistente da Diretoria

Ana Rita Alves Meneses Lima, Chefe da Seção de Edição da Revista

Maria Lúcia Beffa, Diretora do Serviço de Biblioteca e Documentação

Marli Inocência de Moraes, Supervisora Técnica de Serviço

Leonidas Jean Balabakis, Chefe da Seção de Informática

Antonio Augusto Machado de Campos Neto, Editor da Revista e Coordenador da Subcomissão.

Normas editadas em 9 de novembro de 2005. 